\title{
Rancherías: Historical Archaeology of Early Colonial Campsites on Margarita and Coche Islands, Venezuela
}

\author{
Andrzej T. Antczak, Ma. Magdalena Antczak, Oliver Antczak, and \\ Luis A. Lemoine Buffet
}

The frantic nature of the contact period followed by the unrelenting forging of quotidian colonial realities brought dramatic changes to indigenous peoples across the Americas. Each of these phases assumed specific social expressions and pulsated with diverse regional tempos. Undeniably, some threads that interconnected indigenous populations of the late precolonial times were irreversibly severed during the contact period. Other links survived and underwent various processes of transformation. Along the Venezuelan coast and the parallel chain of Southeastern Caribbean islands, the arrival of the Europeans had categorical consequences. It cut off or thoroughly transformed traditional circuits of exchange and spheres of interaction which crossed boundaries of archaeologically defined precolonial cultures and united diverse - protohistorically known - linguistic and ethnic units (Amodio 1991; Antczak and Antczak 2006; Biord Castillo 1985; Biord Castillo and Arvelo 2007; Heinen and García-Castro 2000; Henley 1985; Perera 2000; Scaramelli and Tarble de Scaramelli 2005; Tiapa 2008). Although little is known about the nature of the social processes behind the scene, there is some persuasive archaeological evidence of their operation in the late precolonial and early colonial Venezuelan Caribbean (Antczak and Antczak 2015a, 2015 b; Antczak et al. 2015; Rivas 2001).

Northeastern Venezuela is exceptionally well-suited for archaeological research into the encounter of differing material cultures and socio-cultural transformations in early colonial settings. Since the early sixteenth century, the Spanish were present in this area on the barren island of Cubagua surrounded by extensive pearl oyster beds. There, the town of Nueva Cádiz was officially founded in $15^{28}$. Ever since then, facts and fictions about this town and its inhabitants have played an important role in Venezuelan historiography and anthropology; they have also stirred the imagination of artists. The 'story' 
of Cubagua has played an important role in the (re)formulations of national identity in Venezuela (e.g., Armand 2017; IPC 2009; Suárez 2014).

However, for all its impact on present-day culture, the intricacies of early sixteenth-century Cubagua remained only superficially disclosed by archaeologists. When excavations were carried out on this island in the 1950 s they left behind more questions than answers. The overarching goal of the research backing up this chapter is to thoroughly recontextualize the town of Nueva Cádiz de Cubagua. This is achieved based on new archaeological data from our fieldwork on the islands of Margarita and Coche (Figure 7.1). This data is further compared with the information obtained during the study of collections from Nueva Cádiz, currently held in Venezuelan and North American museums. All this data is also contextualized within the large body of information amassed during the long-term Venezuelan Islands Archaeology Project directed by the first two authors since 1983, allowing for the construction of a solid late-precolonial backdrop and further critical evaluation of early colonial disentanglements, inceptions and transformations (Antczak and Antczak 2015). These activities are part of the ERC-Synergy project NEXUS1492 led by the Faculty of Archaeology, Leiden University in collaboration with several Venezuelan institutions.

In this chapter, we critically merge the archaeological data, documentary sources, and the ecology of the pearl oyster in order to provide a novel understanding of the socionatural conditioning of the earliest colonial settlements on the islands of Margarita, Coche and Cubagua. This chapter opens with a historical contextualization of Nueva Cádiz reviewing previous investigations in the area. Next it discusses the results of the research conducted by the authors. Broad interpretations of early colonial campsites together with suggestions for future research conclude this chapter.

\section{$2 \quad$ Nueva Cádiz de Cubagua: History and Research Antecedents}

Cubagua's pearls achieved European notoriety after Christopher Columbus' third voyage to the New World in 1498 . He was stunned by the natural abundance of pearls and their widespread use as indigenous body ornaments, and baptized northeastern Venezuelan region as the Gulf of Pearls (Golfo de las Perlas) (Colón [1498]1997, 79-80; de Las Casas 1981, 31). Columbus' letter to the Catholic Monarchs of Spain, Ferdinand and Isabella, spread the news across Europe (del Verde [1499]1989; Cantino [1501]1989) and attracted a throng of sailors to the region, also called the Coast or Island(s) of Pearls (Castellanos [1589]1987; de Las Casas 1997; del Verde [1499]1989; Fernández de Oviedo 

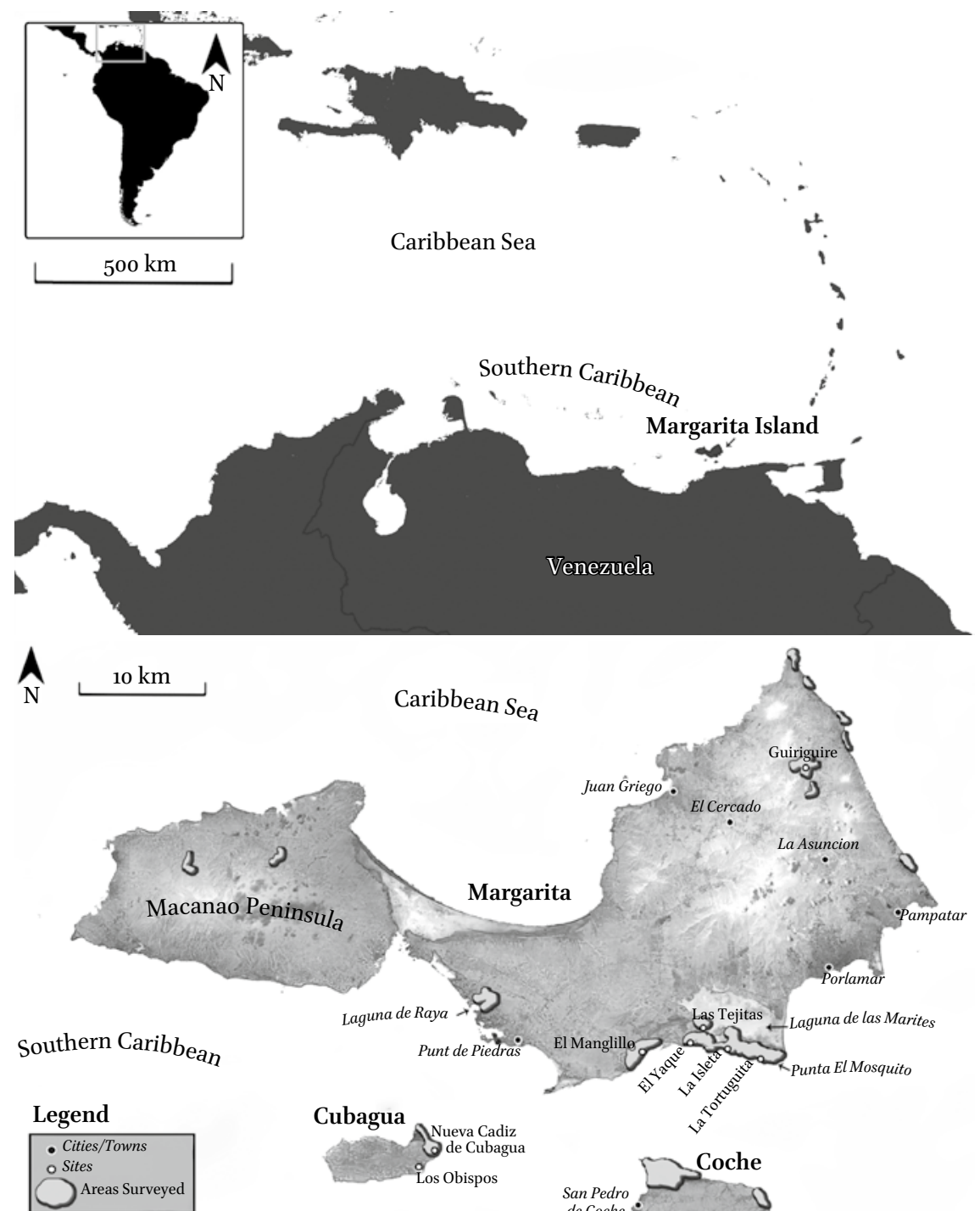

Caribbean $S_{\mathrm{e}_{\mathrm{a}}}$ 
In 1521 , the previously existing cluster of temporary campsites (or rancherías as they were called in documentary sources) was converted into an asiento or administrative seat. In 1526 , the asiento became the villa or town hall of Santiago de Cubagua (Cunnil Grau 2004, 6o), and on the 12th of September 1528, the Cédula Real (Royal Decree) proclaimed the foundation of the ciudad (town/city) of Nueva Cádiz (Otte 1977, 87). After a decade of prosperity, the yields of Cubagua pearls dwindled and a frenetic, but ultimately unsuccessful, search for new oyster beds was performed on almost all of the Venezuelan islands (Arellano Moreno 1950, 180; Ramos 1976, 179-207). By 1538, a new campsite of pearl fishers from Cubagua was established in Cabo de La Vela in present-day Colombia, some $1000 \mathrm{~km}$ to the west (González 2002; Guerra Curvelo 1997; Vásquez 1989). Farther away still, pearls had also begun to be exploited in the Pearl Islands in Panama (Camargo 1983; Cipriani et al. 2008) and in Baja California (Gerhard 1956). By the early 1540s the town of Nueva Cádiz had been abandoned (Vila 1948; see also Vela Cossio and García Hermida 2014).

All in all, Amerindian slaves, pearls and gold, in addition to the quotidian 'bartering' or just forceful stealing of staple foods from the indigenous peoples (maize, cassava and other foodstuffs), triggered and sustained Spanish interest in the exploration and conquest of the northeastern part of South American Tierra Firme through the initial decades of the sixteenth century (Arcila Farias 1946, 1983; Arellano Moreno 1950; Jiménez 1986; Vila 1978).

This eventful period of Venezuelan history has generated much scholarly work in Venezuelan historiography and anthropology (Ayala Lafée-Wilbert and Wilbert 2011; Boulton 1961; Brito Figueroa 1966; Cervigón 1997, 1998a; Cunnil Grau 1993, 2004; Gabaldón Márquez 1988; Morón 1954; Otte 1961, 1977; Rodríguez Velásquez 2017; Rojas 2008; Sanoja Obediente and Vargas Arenas 1999; Velázquez 1956; Vila 1961, 1963, 1978). Topics related to the rowdy and boisterous social life of this early town nourished Venezuelan literature (Azócar de Campos 2009; Nuñez 1988; Pacheco et al. 2006) and cinematography (e.g. Arreaza-Camero 1993), and stirred up the imagination of sixteenth-century engravers (Champlain 1989; de Bry 1990; O'Brian 1996).

However, despite Cubagua's near omnipresence in Venezuelan narratives, these are characterized by three important drawbacks: (1) the heavy emphasis placed on Spanish deeds known from documentary sources; (2) the paucity of archaeologically grounded interpretations where Amerindian and African social actors may yet become visible and endowed with agency; and (3) the emphasis on early colonial urban spaces and lack of studies on the indigenous depopulation and desettlement and European resettlement of non-urban scapes on the islands of Margarita, Coche and Cubagua after 1498. These constraints contribute to the perpetuation of flawed, incomplete and unidirectional grand narratives. 
Although several documents from the early sixteenth century mention the presence of Spanish huts and, later, buildings and urbanized spaces on Cubagua Island, the archaeological evidence of these phenomena was for a long time understudied. In Nueva Cádiz as in the surrounding region, due to the imposition of colonial regimes, indigenous peoples and European newcomers were involved in myriad new entanglements in which ethnic, linguistic, racial, gender and other social statuses were often violently redefined in everyday 'civilizing' practices (e.g., Deagan 2003; Gosden 2004; Silliman 2015; Voss and Casella 2012). The ever-changing nature, dynamics and intensities of these processes inspired international researchers to work on the topic, essentially drawing from rich documentary sources (Bénat Tachot 2015; Dawson 2006; Helmer 1962; Idyll 1965; Mosk 1938; Orche 2009; Perri 2009; Quiévreux 1900; Warsh 2010, 2018; Willis 1976, 1980; Woodruff Stone 2014). The pearl fishery was also approached by historical ecologists (Cipriani et al. 2010; MacKenzie et al. 2003; Romero 2003; Romero et al. 1999). But despite the evident remains of Nueva Cádiz lying in the sands of Cubagua (Rugil 1892), archaeology was long silent. At the beginning of the twentieth century, Leonard Dalton (1912, 183-184) summarized this situation well by arguing that on Cubagua '...diligent search and delving will reveal relicts of the fifteenth-century [this is an error; it should be sixteenth century] settlement [and yet] ... nothing seems to have been done in the way of archaeological excavation....'

The needed excavations were finally carried out in the second half of the 1950s by José Maria Cruxent and his collaborators; but these only half-opened a fascinating Pandora's Box (Cruxent 1955, 1964, 1969, 1972, 1980; Cruxent and Rolando 1961; Cruxent and Rouse 1958; Ferris 1991; Goggin 196o, 1968; Lister and Lister 1974; Rouse and Cruxent 1963; Vaz and Cruxent 1978; Vila 1961; Willis 1976, 1980; Wing 1961). According to Cruxent (1972), the cultural strata in the ruins of Nueva Cádiz lay only at a shallow level. We confirmed this shallowness by analyzing the annotations made by John Goggin who accompanied Cruxent in his initial excavation in December of 1954 as well as the data attached to the objects that are currently held in the Museum of Natural History in Gainesville and in the Peabody Museum at Yale University in New Haven. In general, the maximum depth of the excavation was $40 \mathrm{~cm}$ but approximately $98 \%$ of all excavated units reached only the depth of $15 \mathrm{~cm}$. This resolution precludes any clear-cut spatial or temporal discrimination among the different categories of Amerindian materials from: (1) precolonial times (pre-1498); (2) post-Contact but pre-Nueva Cádiz times (1498-1528); (3) the time span of the town of Nueva Cádiz (1528-1542); and (4) post-1542 to the end of the sixteenth century. In addition, there is no doubt that Nueva Cádiz's boisterous 
lives taking place on the sandy surface of a semi-deserted island contributed to the daily intermingling of the archaeological materials entrapped in the shallow superficial strata. The postdepositional processes that could bias the original deposition include centuries of almost uninterrupted human transit across the ruins associated with trampling, building, transporting loads, preparing and repairing fishing gear, disposing of rubbish, goat roaming, and looting. These processes acted together with natural agents such as winds, tropical storms, salinity, high temperatures, and the bioturbation produced by land crabs (Cardisoma guanhumi and Gecarcinus ruricola), rabbits (Sylvilagus floridanus margaritae), burrowing owls (Athene sp.) and, probably, common rats (Rattus sp.). Finally, the archaeological field methods used in the 1950 os also lacked the microstratigraphical and microcontextual approach, and fine-mesh sieving.

Despite the above weaknesses, some of the intricacies of the contact period on Cubagua began to be illuminated by Cruxent and Rouse (1958) within the perspective of the historical-cultural chronology of north-eastern Venezuela. Close to the La Aduana Archaic Age shellmidden (its beginnings date to $4150 \pm 80$ BP), Cruxent and Rouse $(1958,1,112)$ found a small surface scatter of potsherds painted with straight lines that seemed like the Playa Guacuco style from Margarita. This scatter was dated to between ca AD $115^{\circ}$ and 1500 and classified as a member of the (impoverished) Dabajuroid series from northwestern Venezuela that 'traveled' from there through trade. Cruxent and Rouse found the Playa Guacuco pottery closely related to the early colonial pottery of Nueva Cádiz and to the Los Obispos styles, which purportedly developed subsequently in situ on Cubagua Island.

In 2008, Aníbal Carballo performed an archaeological survey on Cubagua aimed at reconstructing the changing cultural landscapes of the island. Although 36 new sites and 27 isolated features were added to the archaeological map of this island, the survey confirmed the scarcity of Saladoid pottery (Carballo 2014, 16, 79-80, Plano 13; 2017). This singularity was also confirmed by unsystematic surveys conducted on Cubagua by the authors in 2014. Carballo (2014, Planos 14, 15, p. 66, Lám. 25, p. 152) further reported only a small number of Playa Guacuco potsherds and found one potsherd assigned to the Krasky style from Los Roques Archipelago, pertaining to the Valencioid series from north-central Venezuela. Some new data related to the first religious sanctuary of Nueva Cádiz and its cemetery has also been yielded by excavations carried out between 2007 and 2008 by the archaeologist Jorge Armand (2017). Our research into the early colonial settlements on Margarita, Coche and Cubagua began to take shape based on the above-outlined scenario. 
Searching for the archaeological signatures of sixteenth-century campsites, in 2014 we carried out initial surveys of the heavily populated town of Punta de Piedras on Margarita Island as well as in the surroundings of the ruins of Nueva Cádiz de Cubagua. These attempts produced archaeologically unsatisfactory results. Therefore, our attention moved eastwards towards the southeastern coast of Margarita and to Coche Island where four pedestrian archaeological surveys were undertaken throughout 2015 and 2016. These included systematic monitoring of surface in a strip of ca $500 \mathrm{~m}$ along the coasts and the excavation of test pits and small trenches. In the next sections we focus on material remains recovered at two sixteenth-century sites: La Tortuguita on Margarita and El Guamache on Coche Island.

\subsection{Margarita Island \\ 3.1.1 Documentary Sources}

The number of early historical sources related to the southeastern Margarita is very limited. Subero $(1996,132)$, drawing from unspecified documents, assures that the first dwellings were erected by European pearl seekers not only on Cubagua but also on the southeastern coast of Margarita as early as August of 1509. Some other sources put the origin of rancherías on Cubagua at the very beginning of the sixteenth century (Benzoni $[1565] 1991,570$ ). This early origin, however, was erroneously attributed to de Las Casas's time-independent statement (de Las Casas 1981, 25). Here, we use the date of 1516 as the documentarily supported origin of the early Spanish rancherías on Cubagua (Otte 1977, 87). Nonetheless, we are aware that the gargantuan profits offered by the bountiful pearl oyster beds drew European pearl seekers to these islands very soon after the year 1500 .

\subsubsection{Archaeological Evidence}

The "Punta Mosquito" site on Margarita was mentioned by Theodoor de Booy $(1916,11-12)$ as "a favourite abode of the aborigines." We presume that he did not refer exactly to the site that currently bears that name on the most southeastern point of Margarita, because it shows a rather inhospitable environment to be an "abode." De Booy (1916, Figure 3) further stated that pearl oyster shell deposits found on the shore dunes at "Punta Mosquito" and interspersed by layers of ash could be interpreted as the remains "from early Spanish pearl fisheries." According to our surveys, these shell deposits had to be situated to the west of Punta Mosquito, somewhere between the El Manglillo and El Yaque sites (Figure 7.1b). Towards Punta Mosquito, the coast not only is barren 
and hardly accessible to canoes but farther to the east - especially around the La Tortuguita site - colonial remains are very abundant, visible on the ground surface and cannot go unnoticed.

Cruxent and Rouse $(1958,1,117)$ mentioned "Punta Mosquito" and the archaeological site of "Los Mayas" on the southeastern coast of Margarita. This site, pointed out in the first volume of the above referenced publication, corresponds, most probably, to the "Las Maras" site that is marked on the map provided in the second volume (Cruxent and Rouse 1958, 2, Figure 11). There, the "Las Maras" site is adjacent to "Punta Mosquito," the southeasternmost tip of the island. We conclude that it is this site that coincides with the La Tortuguita site that was found during our surveys. Cruxent and Rouse $(1958, \mathrm{I}, 117)$ further stated that Las Maras yielded some European pottery from the sixteenth and seventeenth centuries and assigned it to the Obispo style (post-Nueva Cádiz dated to ca 1622-1640; but see Cruxent and Vaz 1978, 369). However, they recognized that scarce European materials found in this and other surface scatters across the Macanao Peninsula (the western part of Margarita), at the Güirigüire (eastern Margarita), and in Guamache on the island of Coche, all included by them in the Obispo style, may in fact be classified in future research as an independent style (Cruxent and Rouse 1958, 1, 117-118). The only decoration found on the associated (possibly) transformative ceramic materials consists of rectangular or tubular appendixes or false handles applied to the shoulders of the vessels (Cruxent 1980, 174; Cruxent and Rouse 1958, 1, 118)

Our surveys yielded new archaeological data from several colonial sites located on Margarita and Coche islands. But before turning to discuss in more detail the sites of La Tortuguita (Margarita) and Guamache (Coche), let us briefly introduce the related sites of El Manglillo and El Yaque (Margarita) whose locations were indicated to us by Mr. Luis Lemoine (Fundación Arca, Caracas) (Figure 7.1b). They were surveyed in 2015 with Luis Lemoine, Cecilia Ayala and Pedro Rivas (Fundación La Salle de Ciencias Naturales, Caracas), and Werner Wilbert (Instituto Venezolano de Investigaciones Científicas, Caracas). The El Manglillo site features a series of dune formations covered with xerophytic plants and is crosscut by deep ravines conducting rainwater to the sea. Fragments of Spanish olive jars and Columbia Plain dishes dated to the first half of the sixteenth century and sherds of coarse earthenware, probably of local transcultural production, were recovered on the dunes (Luis Lemoine, personal communication 2015). Test pits of $1 \times 1 \mathrm{~m}$ were excavated but only one trench of $2 \times 9 \mathrm{~m}$ situated on the slope of a large dune revealed a cultural layer at a depth between 20 and $65 \mathrm{~cm}$. It yielded ceramic materials like those found on the surface as well as bivalve shells, fish vertebrae, and the features of four hearths. These fireplaces could easily be seen from the sea as well as 
from inland both day and night indicating that the camp was not a clandestine location. The environmental characteristics of the El Yaque site, located on the western border of Laguna de Las Marites, are similar to those of El Manglillo. A test pit of $2 \times 1 \mathrm{~m}$ and a small trench of $2 \times 5 \mathrm{~m}$ were excavated revealing a cultural layer of greyish sand at a depth between 15 and $35 \mathrm{~cm}$. Hearths are absent. Ceramic materials are overtly like those found at El Manglillo. Small patches of bivalve shells show rather marginal dependence on locally available marine resources. The mandible of a non-local deer (Odocoileus virginianus) suggests that game was brought from the adjacent mainland. El Manglillo and El Yaque most probably did not host a well-established group of rancherías, but represented the remains of recurrent encampments under the open sky taking advantage of the benign climate and sandy seacoast. These camps may be a result of intense mobility on the part of largely 'amicable' indigenous peoples who interacted with the Spanish in pearl fishery provisioning. They indicate a rather 'safe' atmosphere that, according to Juan de Castellanos ([1589]1987, 120-123), a resident of Nueva Cádiz, characterized the Spanish emplacements on Margarita in the 1520 and 1530 s.

The site of La Tortuguita is located between the modern settlement of La Isleta and Punta El Mosquito (Figure 7.1b). To the north, a sandy shore gives way to hypersaline lagoons that produce salt. Behind the saltpans, the terrain rises slightly and undulates with small hills cut by ravines serving as cones of ejection for sporadic but heavy rains. The vegetation is largely xerophytic (Campos and Guzmán 2002); firewood and permanent freshwater reservoirs are absent (Rojas 2010). The terrain is hardly apt for agriculture and except for rabbits and snakes, the land fauna is poor. We cautiously assume - until new, especially paleobotanical, evidence can test the matter - that similar semi-deserted conditions existed in this area during the sixteenth century. Several surface scatters of sixteenth-century pottery and other materials were found dispersed in patches across one square kilometer at this site (Figure 7.2d, e). Test pits showed that the material may be found to a depth of $15^{-25} \mathrm{~cm}$. This fact, together with the discovery of one fragment of Spanish stucco or plaster, makes us confident that postholes and hearths of sixteenth-century rancherías and probably later estancias, or homesteads, are possible finds in future research.

The surveys at La Tortuguita yielded hundreds of archaeological remains. The quantity and variety of pottery shows a wide range of techniques and decorative motifs ascribed to European along with Amerindian manufacture (Figures 7.3-7.5). There are also possible transcultural or hybrid wares that seem to contain both European and Amerindian characteristics (Figure $7.5 \mathrm{~d}-$ f). Future analytical scrutiny may also identify elements of African origin. The presence of more permanent dwelling structures may further be strengthened by the recovery of stone grinding tools (manos and metates), ceramic griddles, 


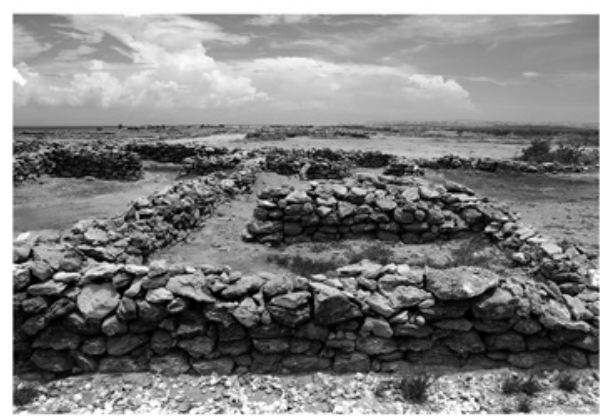

a
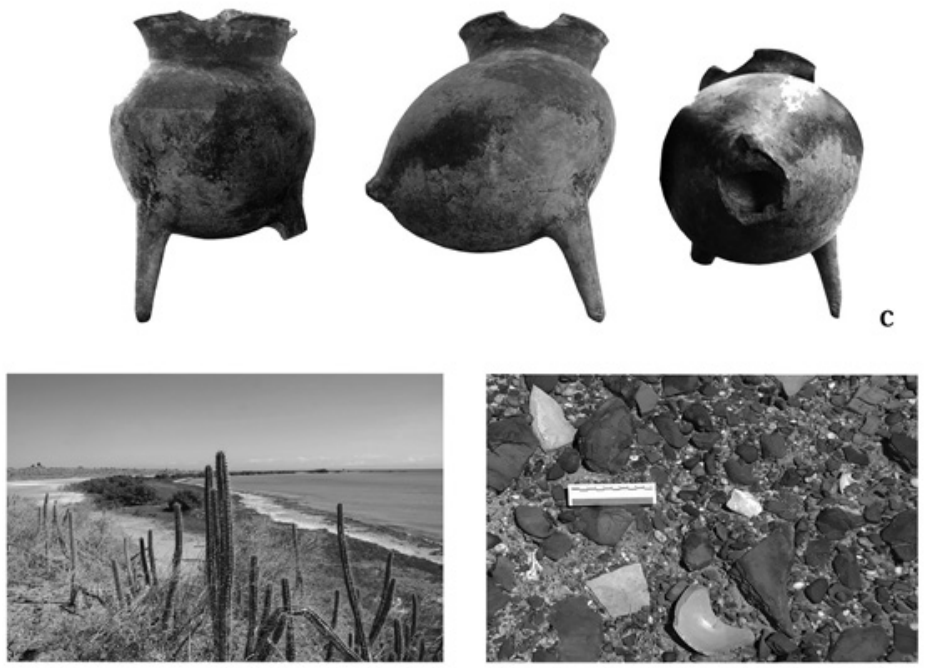

d

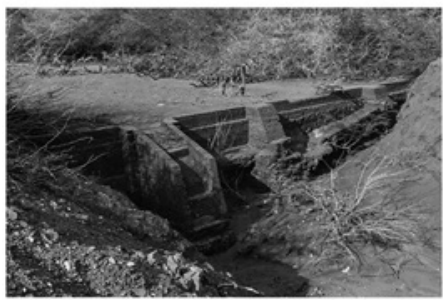

f

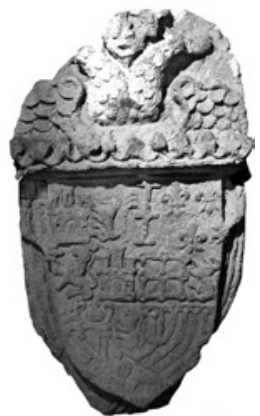

b
C

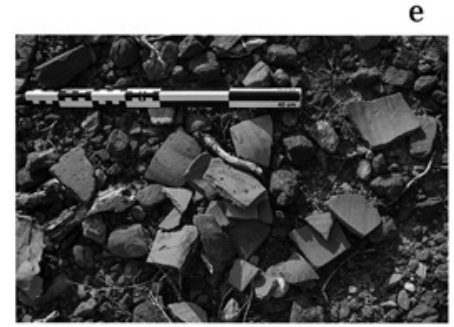

g

FIGURE 7.2 Sites and materials: (a) ruins of Nueva Cádiz town in 2014, Cubagua; (b) coat of arms of Nueva Cádiz, stone, Museo de Nueva Cádiz, Asunción, Margarita; (c) large tripod vessel with red-slipped upper body part, found in Nueva Cádiz in 1950s, probably Amerindian pottery but of undefined stylistic affiliation, height $28.5 \mathrm{~cm}$, Museo Marino, Punta de Piedras, Margarita; (d) view from La Tortuguita westwards to Punta Mosquitos, Margarita; (e) scatter of Spanish pottery, La Tortuguita, Margarita; (f) abandoned dam with 'old' stony foundations, Guamache, Coche; (g) scatter of Spanish olive jar fragments, Guamache, Coche 


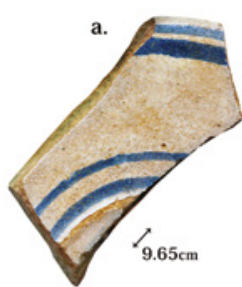

d.
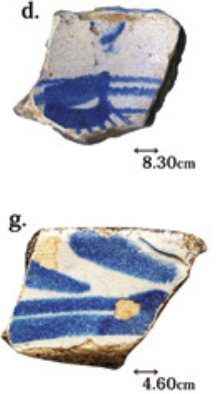

h.
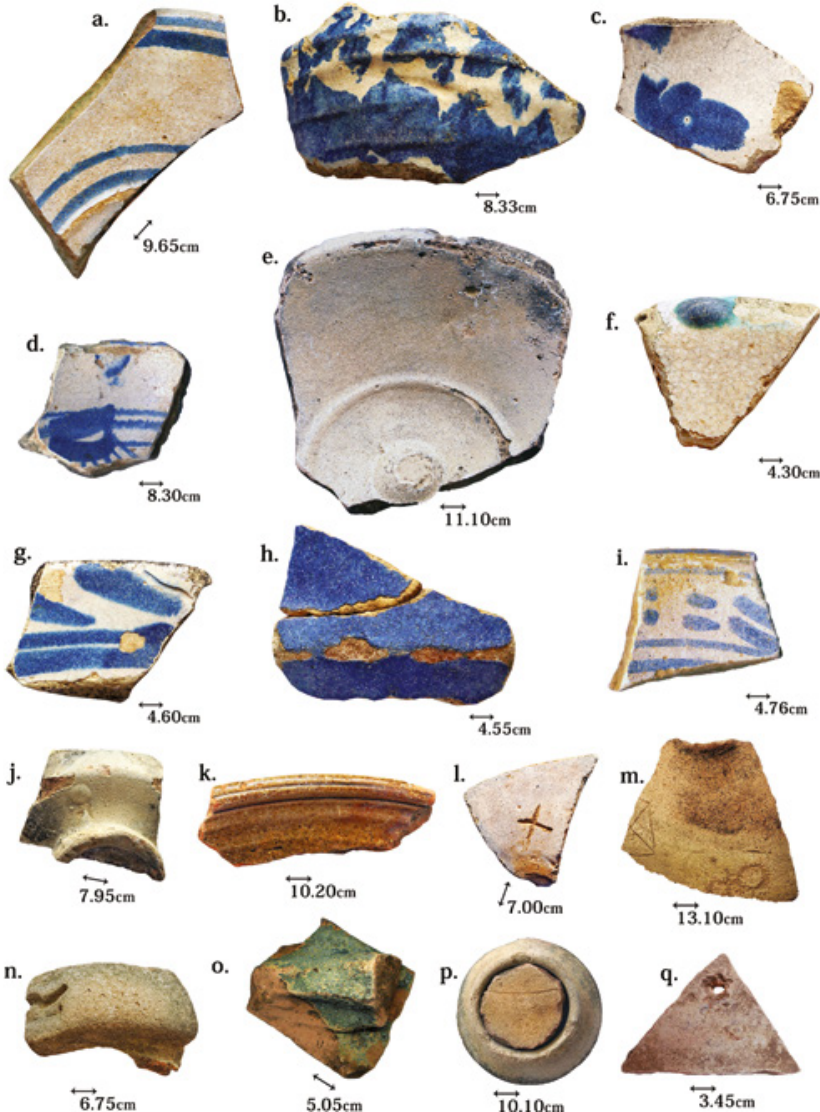
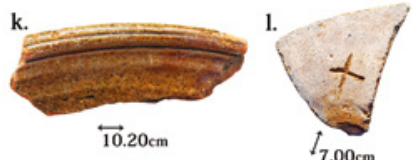

o.
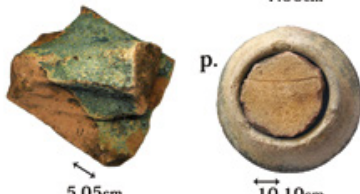
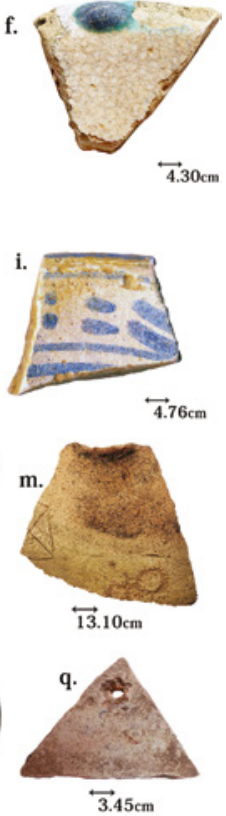

FIGURE 7.3 Selection of primarily sixteenth-century European ceramics from Margarita, la Tortuguita, and Güiri-güire, Venezuela (surveys 2014-2016): (a) linear Blue Morisco Ware, plato (plate), Seville, prob. pre-1550 due to well-defined angle between the rim and the center of the interior surface; (b) Mottled Blue Morisco Ware, jarro (jug), Seville, ca. 1550-1625; (c) Decorated Blue Morisco Ware, jarro, Seville, ca. 1550-1625; (d), Decorated Blue Morisco Ware, cuenco (bowl), Seville, ca. 1550-1625; (e) Plain White Morisco Ware, plato, Seville, pre-1550 due to marked central boss and well-defined angle between the rim and the center of the interior surface; (f) Plain White Morisco Ware with Green Edge, cuenco, Seville, prob. pre-1550; (g) Decorated Blue Morisco Ware, plato, Seville, ca. 1550-1625; (h) Plain Blue Morisco Ware, escudilla or albarello, Seville, ca. 1500-1570; (i) Decorated Blue Morisco Ware, cuenco, Seville, ca. 1550-1625; (j) Plain White Morisco Ware, escudilla, Seville, prob. pre-1550; (k) Lead-glazed red earthenware, plato, prob. Seville, prob. sixteenth century; (l) Plain White Morisco Ware, plato, Seville, pre-1550, with possible owner's/user's mark on back; (m) Spanish botija (olive jar) with incised mark on shoulder; (n) Spanish botija rim with impressed mark, Seville, sixteenth to mid-seventeenth century; (o) Spanish green lead-glazed cantimplora, Seville, pre-155o; (p) Spanish botija rim with disk-shaped botija sherds probably used as stoppers, Seville, sixteenth to mid-seventeenth century; (q) perforated triangular Spanish botija fragment, Güiri-güire 


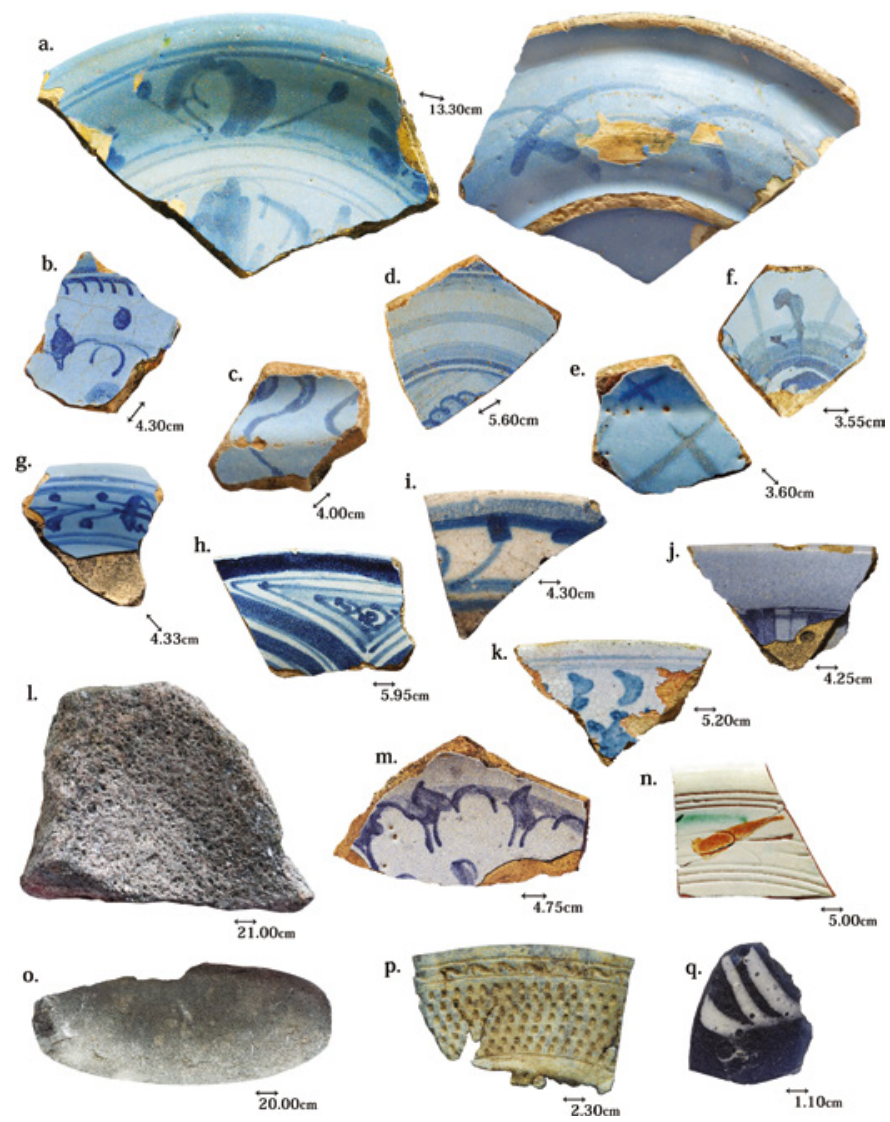

FIGURE 7.4 Selection of late sixteenth/seventeenth-century materials from Margarita, La Tortuguita site, Venezuela (surveys 2014-2016): (a) Ligurian berettino majolica, with calligrafico a volute design, bowl, late sixteenth to first quarter of seventeenth century; (b-f) Ligurian berettino majolica, plate, late sixteenth to first quarter of seventeenth century; (g) Ligurian berettino majolica, with calligrafico a volute design, bowl, late sixteenth to first quarter of seventeenth century; $(\mathrm{h})$ possibly Portuguese Blue on White faience, plate, $1625^{-1650}$; (i) Seville Blue on White ware, plato, late sixteenth to mid-seventeenth century; (j) Ligurian berettino majolica, bowl, late sixteenth to first quarter of seventeenth century; (k) Ligurian Blue on White majolica, plate, second half of sixteenth to first half of seventeenth century; (l) fragment of lithic metate; (m) Ligurian Blue on White majolica, plate, second half of sixteenth to first half of seventeenth century; (n) polychrome lead-glazed graffita tarda, plate, Pisa, ca. 1550-1650; (o) lithic mano (grinding stone/percutor); (p) flattened copper-alloy thimble; (q) fragment of hand-blown blue glass with painted white enamel, prob. Venetian, sixteenth or seventeenth century 

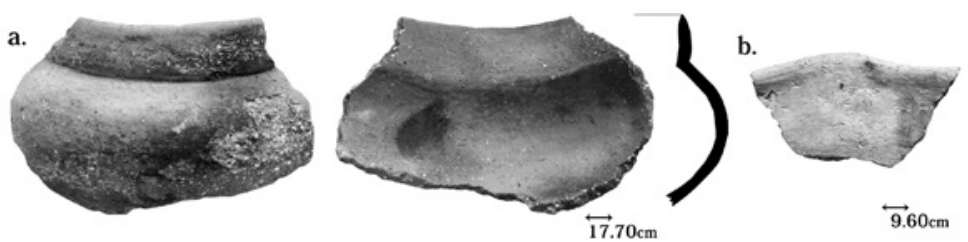

c.
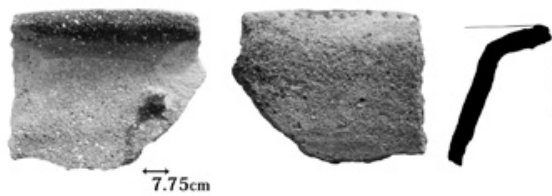

d.

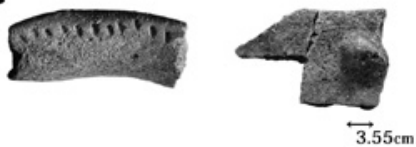

e.
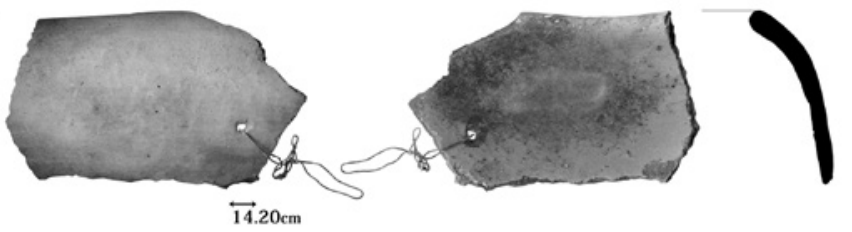

f.
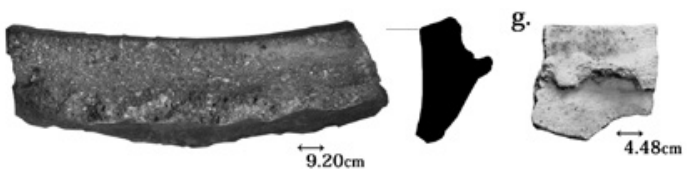

h.

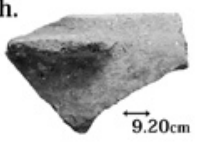

i.
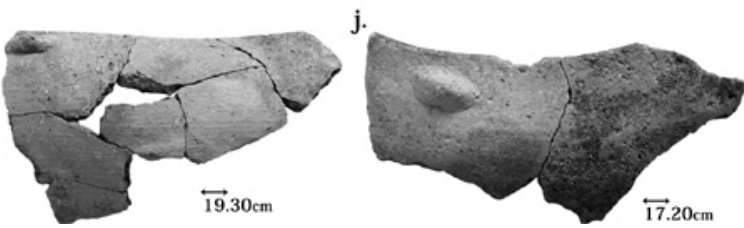

k.

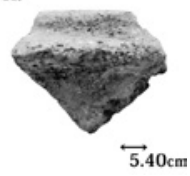

FIGURE 7.5 Indigenous transformative wares (sixteenth-seventeenth century) and criolloware (eighteenth-nineteenth century) from Margarita, Venezuela (for localities see Figure 7.1 [bottom]): (a) large indigenous cooking olla, La Tortuguita, prob. sixteenth or seventeenth century; (b) wavy-shaped and externally red-slipped rim, open bowl, Las Tejitas, prob. eighteenth-nineteenth century; (c) open bowl rim, incised on lip's internal side, a small knob or false handle on shoulder, La Tortuguita, prob. sixteenth or seventeenth century; (d) bulbous pellet applied to the shoulder of red-slipped indigenous bowl, La Tortuguita, prob. sixteenth or seventeenth century; (e) fragment of large restricted bowl, perforated and with copper wire attached to it, La Tortuguita, sixteenth-nineteenth century; (f) wavy strip or 'false' handle applied around the shoulder of open bowl, El Manglillo, prob. eighteenth-nineteenth century (similar decoration still produced by potters in El Cercado, Margarita); (g) wavy protuberance with digital impressions, Las Tejitas, prob. nineteenth century; (h, k) possible false handles, Las Tejitas, prob. nineteenth century; (i-j) bulbous pellets on shoulders of large restricted bowls, La Tortuguita, sixteenth-nineteenth century 
and many spatially concentrated fragments of olive jars presumably reused to store freshwater. These artifacts accounting for food preparation and consumption rather than food procurement indicate that the staple food was brought rather than produced in situ. The absence of metal tools compared to the presence of multifunctional indigenous tools made of quartz indicates that Amerindian peoples inhabited the La Tortuguita site together with the Spanish (peninsulares and criollos), and probably also with enslaved Africans and mestizos

All these characteristics may have met the requirements of the early colonial pearl fishery rancherías but the occupation of La Tortuguita site lasted much longer. European pottery reveals that the occupation of this site could have started contemporaneously with Nueva Cádiz, i.e., somewhere in the early 1520s. It continued across the colonial times, far beyond the demise of Nueva Cádiz in the early 1540 . A map from 1661 drawn by the Spanish military engineer Juan Betin depicts some forms of habitation west of Punta El Mosquito that could coincide with the La Tortuguita site (Nectario Maria 1960, 131-136). Also, fragments of blue shell-edged whiteware, red clay pipes, and nineteenth-century case bottles collected during our surveys indicate that this site was still inhabited or temporarily frequented during the late eighteenth and nineteenth centuries (von Humboldt [1814-1825]1995). Fishery of the pearl oysters in front of Punta Mosquitos and on Coche was active between 1845 and 185 os (Quiévreux 1900, 446). Through time, the settlement at La Tortuguita would have gradually lost its initially purely temporal character, which was akin to some other encampments on Margarita before 1536 (Cunnil Grau 2004, 63). According to the documents its occupation would fluctuate according to the erratic pearl fishery. It would become more permanently inhabited as it transitioned into a multifunctional colonial ranch (estancia), or it could even have been temporarily abandoned. Remarkably, the persistent presence at almost all surveyed sites of hand-coiled coarse red earthenware indicates the continuous use of locally made pottery (cerámica criolla). Some of its forms and decoration derived from the town of Nueva Cádiz, persisted in the postNueva Cádiz rancherías, and seem to be still alive today in the locally made traditional pottery from El Cercado in Margarita (Acosta Saignes 1964; Gómez 2004, 160-162, 184; Ocanto and Baptista 1998) as well as from Manicuare, near Cumaná on the adjacent mainland coast (Ginés et al. 1946).

The elements that would have been deemed attractive and, therefore, could have pulled sixteenth-century settlers into the La Tortuguita site, were the proximity to (1) harbors and sandy shores; (2) pearl oyster beds; (3) fishing and mollusk-gathering grounds; (4) saltpans; and (5) pasture for goats. Also, the visibility from the hilly terrain towards both the sea and the interior of Margarita would have permitted the monitoring of the seascape traffic 
between Margarita, Coche, Cubagua and the mainland. However, fresh provisions such as fruits, vegetables, meat and water had to be brought by canoes or accessed from inland localities of Margarita.

\subsection{Coche Island}

\subsubsection{Documentary Sources}

The Island of Coche appears in Spanish documents beginning in mid-1520. On the 27th of August, 1520, the Spanish Crown granted a license to Juan de Cárdenas to "establish the seat of the barter of pearls [asiento de rescate] in Cubagua, [and] to get pearls on Coche [Island] and in Punta de Araya [on the adjacent mainland]" (Subero 1996, 143). On July 28th, 1526, the island was entrusted (encomendada) to Juan López de Archuleta (Subero 1996, 127), a member of the elite in Nueva Cádiz and the owner of two pearl fishing canoes (señor de dos canoas) (Otte 1977, 50). The Cédula Real of this assignment describes an island called Conche, a name derived from the Spanish name concha (shell) and not, as suggested by Bartolomé de Las Casas (1981, 32), from a small local deer still abundant on this island during late colonial times (von Humboldt [1814-1825]1995, 74). The island was "[F]rom 2 to 3 leagues around, uninhabited and without being previously entrusted to any other person, and because he [Archuleta] wanted to have in it his cultivation, animal and cattle breeding and other husbandry in order to provide provisions for his farmhouse and [for the benefit] of that island" (Otte 1961, 12-13). In 1799, Alexander von Humboldt ([1814-1825]1995, 47) was informed by local indigenous informants that Coche "...had never been inhabited [by the indigenous peoples]."

In 1529, according to the letter that Diego Caballero (resident of Nueva Cádiz) sent to King Carlos v, rich pearl oyster beds were discovered close to Coche (Morón 1954; Pinto 1967; Subero 1996, 46). During solely the month of January 1529 , more than 1,500 marks (12,000 ounces) of pearls, the equivalent of over 17 million carats, were gathered from the pearl beds of Coche (Galtsoff $1950,4)$. By this year, other Spaniards already had granjerías (husbandry operations, in this case dedicated to pearl fishing) on Coche and some royal officials were already established there (Otte 1961, 108-110). In June of 1529, the Queen wrote that Hernando Carmona, the bailiff (Alguacil Mayor) of Nueva Cádiz, had informed her that because of the discovery of rich oyster beds, many people who lived in Nueva Cádiz town had moved to Coche. Carmona even asked the Court for permission to use the title of Alguacil Mayor of Cubagua on Coche (Subero 1996, 104). A month later, probably as the result of the burgeoning pearl boom, the Court unveiled immediate plans for the establishment of a "village of Christians" (pueblo de cristianos) on Coche including the services of a clerk and a village council (Subero 1996, 112). The new oyster beds were large, 
and their discovery was not a short-lived boom. Still by 1573, the bishop Fray Pedro de Agreda was informing the Crown that Coche was benefitted by its "generous" pearl oyster beds (Agreda [1581]1964; Subero 1996, 199).

Drawing from these documentary sources, it becomes clear that specific sectors of Coche Island were visited by Europeans from the early $15^{20}$, if not before. Later, these sites were populated by the owners of the canoes (señores de las canoas) plus their Amerindian slaves and household servants (naborías). As Nueva Cádiz de Cubagua was the only Spanish town in northeastern Venezuela during the first decades of the sixteenth century, the earliest settlements on Coche Island most probably took the form of rancherías of pearl fishers.

\subsubsection{Archaeological Evidence}

During the survey of Coche Island, we located a few Archaic through Ceramic Age sites and materials which are currently under analysis. The only sixteenthcentury site was found in Guamache. Overly, the archaeological evidence on Coche is very scarce compared to other Venezuelan islands (Antczak and Antczak 2006).

The Guamache site, briefly mentioned by Cruxent and Rouse (1958, vol. I, 117, vol. 2, Figure 7), yielded some European pottery assigned to the sixteenth and seventeenth centuries and classified as belonging to the Obispo style. It is located on the southeastern shore and close to the largest contemporary artisanal fishery port on this island (Figure 7.1b). Similar to La Tortuguita, the terrain is hilly, covered by xerophytic vegetation and cut by deep ravines. The location of the port is privileged: boats can be safely beached there, contrary to the rather cliffy windward coast to the northeast. One of the site's great assets is that the deep ravines could be easily connected and closed by a simple dam fashioned to conserve the freshwater (Figure 7.2d). Today abandoned, the dam still presents its stony structure with bases that may date to colonial times when settlers could also have stored up freshwater in this manner. However, an unquestionable signature of the existence of such a dam in early colonial times did not emerge in our survey even if the dam lies only a few hundred meters from the seashore and from the hilltop where the archaeological remains were found. The southern slope of the hill closest to the port contained scatters of Spanish olive jars and majolica (Figure 7.2e). Three test pits of 1xım excavated on this slope provided no evidence whatsoever of a cultural layer under the surface. Yet we continue to presume that the hilltop may still contain some structural remains (e.g. postholes, remains of adobe walls) of earlier rancherías which could have been established here in or near the 1520s. Some cultivation of land and grazing (mainly goats) could have been carried out in the past on the slopes of the hills. Their tops could, at the same time, have provided a 
fresher climate while offering ample strategic views towards the surrounding seascape and the mainland coast. All these locational advantages might have been attractive to early colonial settlers.

\section{Pearl Oyster Ecology Comes to the Fore}

The marine conditions between the islands of Margarita, Coche and Cubagua and the mainland peninsulas of Araya and Paria, conditions featuring seasonal upwellings bringing deep cold waters rich in nutrients to the surface (Villamizar and Cervigón 2017), have been indicated as highly beneficial for the thriving of mollusk communities - especially large pearl oysters (Pinctada radiata) (Capelo and Buitrago 1998). The abundance of these mollusks in the local waters shines important light on the study of human-environment interactions some of which might have been anthropogenically manipulated during the contact period (MacKenzie et al. 2003). In fact, ecologists have documented the existence of large pearl oyster beds along the coasts of Cubagua where an early sixteenth-century pearl fishery flourished (Carballo 2014, Lám. 47, p. 165; Romero 2003; Romero et al. 1999; Tagliafico et al. 2012). Large oyster populations were also indicated off the southeastern coasts of Margarita and Coche (Romero 2003, Figure 2). Statistical information collected during the 193os and 1940s (Donkin 1998, Map 38; Galstoff 1950, Figure 1 and Table 2) documented pearl oyster beds facing the sites of Los Mosquitos, La Isleta, and El Yaque on the southeastern coast of Margarita, and fronting the southeastern coast of Coche. Salaya and Salazar (1972, Tables 1, 12, 17, Maps 1, 3, 4, 6, 8-10, 13) compiled pearl oyster fishery data collected between 1946 and 1969. These data show the persistent importance of the above-mentioned oyster beds. It is very important for this research to emphasize that the current location of rich pearl oyster beds coincides with the data provided by the early colonial documentary sources. This indicates the persistence of these beds in question across five centuries. Our research underlines that their current location is adjacent to the archaeological sites identified during the recent archaeological surveys. Thus, the material culture recovered at the sites of La Tortuguita on Margarita and Guamache on Coche (Figures 7.2-7.5), confirms the existence of sixteenthcentury campsites at these sites corresponding to the historically documented pearl fishery. These sites might have endured through time, changing their character from temporary to permanent and from monofunctional to multifunctional. The adjacent oyster beds could also have undergone qualitative transformations. This has already been noted for the oyster beds at Cubagua. There, once-enormous aggregations of pearl oyster have been largely replaced 
by Turkey Wing (Arca zebra), the species currently more profitable for its protein content (Casas et al. 2015; Cervigón 1997, 1998a, 1998b; Hernández-Ávila et al. 2013).

\section{5}

\section{Concluding Remarks and Future Research}

The material remains discussed in this chapter were recovered during pedestrian surveys and surface collection offering little information about connections between scattered artifacts. Aware of these constraints, we confronted the recovered materials with pertinent documentary data and environmental and ecological variables. In this way we opened new avenues for further inquiry rather than provided final interpretations into the specific forms and dynamics of interaction between indigenous, African and European peoples and their material culture.

Drawing from the above insights we consider that further research in the field should adopt new methodological characteristics. Surveys should look to systematic large-scale aerial excavations to discover contextually bounded signatures of housing structures and delineate settlement layouts, in their stratigraphic sequences. Understanding the palimpsestic character of the archaeological deposits may prove especially fruitful at sites such as La Tortuguita and Guamache. This will allow us to bring the sixteenth-century rancherías to life and help us understand how, during the twilight of the early town of Nueva Cádiz de Cubagua, Spanish power was also expanding over the adjacent islands of Margarita and Coche.

Comparisons of the spatial organization of the above discussed sites with other similarly excavated colonial contexts in the region may permit the evaluation of transformations in the organizational principles and interactions of the pluralistic collectives that inhabited them. Understanding the past vibrant lives of what today are potsherds, lithics, glass and metal fragments, animal remains, and hearths scattered across the islandscape is crucial to this intellectual undertaking. However, in this chapter we have only begun to explore how from the archaeological perspective - European and natives co-participated in the creation and transformation of larger social trends on the early colonial islandscapes of Margarita, Coche, and Cubagua. Further tasks require stretching the 'social imagination,' which must be in agreement with soundly recovered, identified and dated material culture that is itself in constant juxtaposition with documentary sources and environmental variables.

Accurate identification and dating of the recovered materials is essential. This chapter places special emphasis on determining the origin of European 
wares due to the necessity of dating the occupation of identified campsites and discussing their co-existence, or lack thereof, with the town of Nueva Cádiz. While analyzing the materials found at the colonial site of Maurica (near the modern town of Barcelona) currently at the Museum of Natural History in Gainesville (Rouse and Cruxent 1963, 132, 138-139) we realized that they were initially dated to $1620-1640$ (Cruxent and Rouse 1958, vol. 1, 202). However, some of them may date to the sixteenth century (see also Cruxent and Vaz 1978) and indicate the expansion of Spanish power to the adjacent mainland coast during the time of existence of Nueva Cádiz.

Activities such as food provisioning and preparing, freshwater storing, firewood hauling and chopping, fireplace preparing and maintaining, shade and rain shelter erecting, post hammering, mollusk crushing, maize and coarse salt grinding, fishing net mending, and bartering with close and more distant neighbors all may have been largely intended human actions. But people themselves "are not always engaged in activities that have a clear objective" (Thomas 2017, 281). Artifact use at a specific site can be highly ambiguous, and often not the one intended by the producer (Silliman 2009, 213-214). We should also consider activities which were not merely labor-oriented, those which contributed vibrancy and lifelike texture to past human lives. Although such activities do not often leave material signatures, nevertheless, talking, praying, joking, smoking, resting, gaming, admiring, as well as those activities related to sex and hygiene, have formed an important part of ranchería life. None of these activities may be considered exclusively related to pearl fishery, but gave life to the early colonial rancherías and contributed to their endurance and transformation observable through the passing of colonial times.

We have discussed how the early colonial power's rapacious devouring of human and other-than-human resources was operationalized through the ranchería campsites and their material culture. The Spaniards were engulfing the different groups of indigenous peoples in myriad swiftly shifting scenarios of interaction and, at the same time, accumulating the native space in their non-native hands. In, around and through the rancherías, the New World was being forged by and for both the autochthons and the newcomers. But the temporary or seasonal early colonial ranchería as a specific unit of work and life has deep precolonial antecedents that precede the symbolic date of 1498 which marks the Third Voyage of Columbus. Therefore, a sound understanding of the late precolonial backdrop is necessary to study the early colonial disentanglements, transformations and enduring elements concomitant with European arrival.

With the passing of colonial time, some rancherías, such as those at La Tortuguita, may have lost their earliest, largely unifunctional character which derived from the activities related to pearl gathering that permeated interactions 
among Spaniards, Amerindians and Africans. The human components of these interactions also lost their initially relatively clear-cut ethnic, cultural or linguistic distinctions. Human relations then became largely structured by the colonially created racial distinctions (e.g. Mira Caballos 1997). Remarkably, in northeastern Venezuela, the very first generation of post-Contact Americans included such historically renowned mestizos as the conqueror Francisco Fajardo who was the son of Doña Isabel - a Guaiquerí Indian woman from Margarita - and the Spanish lieutenant Francisco Fajardo (Ayala Lafée-Wilbert and Wilbert 2011; McCorkle 1965). The category of social actors embodied by Fajardo should be considered when studying intercultural interactions in rancherías, especially in view of the fact that these Spanish-induced settlements of precolonial origin played an important though barely understood role in the early political-administrative structure of colonial northeastern Venezuela (Castillo Hidalgo 2005, 216).

In fact, we argue that precisely in this region it is in rancherias where the origin of several colonial transformations should be sought. They were par excellence "transculturation sites" sensu Domínguez (1978). To date, we are still unable to say much about the specificities of these interactions and transformations but diverse activities (e.g., pearling and goat grazing) could have occurred within the same islandscape in multifunctional rancherías, according to diversified task distribution and task timing. The extractive colonization so characteristic to early colonial encounters exploited native labor and local resources and influenced new habits and thoughts of peoples who clearly coexisted spatially and often shared the materiality referred to in this chapter. Acknowledging the latter fact is not to deny the ubiquitous presence of unequal power that endorsed further divisions and marginality (Silliman 2014, 68).

Finally, crucial is the critical interweaving of independent lines of evidence stemming from archaeology, archaeometry, archival research, ethnohistory, ethnography, experimental research, linguistics, descendant perspectives, and oral lore to examine possible convergences and contradictions. Both, the Nueva Cádiz town and the rancherías were an integral part of colonial scapes and their transformations were influenced by a fluctuating combination of socioenvironmental factors (e.g., Sluyter 2001, 411). In the case of Nueva Cádiz town, further research is necessary to examine natural factors such as reduced rates of accretion associated with low seawater temperatures and increased salinities in the Caribbean during the Little Ice Age that could have played an important role in the demise of its pearl fishery (Cipriani et al. 2010). Also, our research discussed in this chapter suggests that the ultimate collapse of the town may be related to the great versatility of temporary rancherías. The latter could be a more flexible and convenient spatial means to expand Spanish 
colonial influence beyond the stony walls of Nueva Cádiz' urban structure that embodied immobility and rigid centrality. In rancherías shared histories were being forged (Harrison 2014) and activities-centered life unfolded (Ingold 2007). Being the most popular form of settlement persistently utilized across the centuries, rancherías continue to thrive along the coasts and on the islands of the Southeastern Caribbean to the present day.

\section{Acknowledgments}

We thank Dan Bailey for valuable comments and Konrad A. Antczak for great insights and the identification of European pottery. Many thanks go to Cecilia Ayala Lafée-Wilbert and Werner Wilbert, as well as to Pedro Rivas, who actively participated in the early fieldworks and contributed with their knowledge, local contacts and experience. We also thank Fernando Cervigón ( $\dagger$ ), Bladimir Rodríguez, Teobaldo Castañeda, and Pablo Rodríguez from the Museo Marino de Margarita, and Grecia Salazar from Museo de Nueva Cádiz in Asunción. We express gratitude to our friends from Margarita: Régulo Briceño, José Voglar, Pablo Segundo Mata, Pavel Nuñez ( $\dagger$ ), Emanuel Narváez (Nelo), and Fernando Fernández. We acknowledge the companionship of the Venezuelan ONG Provita group. The Instituto del Patrimonio Cultural issued the respective permissions and the Guardia Nacional protected us during the fieldwork. This project has received funding from the European Research Council under the European Union's Seventh Framework Programme ( $\left.\mathrm{FP}_{7} / 2007-2013\right)$ ERC Grant agreement No. 319209, under the direction of Prof. dr. C.L. Hofman.

\section{References}

Acosta Saignes, Miguel. 1964. "Cerámica de El Cercado, Margarita." Anuario 1: 1-20. Agreda, Pedro de. (1581)1964. "Relación de la Provincia de Venezuela, hecha por el Obispo de Coro, año 1581." In Relaciones Geográficas de Venezuela, compiled by Antonio Arellano Moreno, 221-231. Caracas: Biblioteca de la Academia Nacional de la Historia.

Amodio, Emanuele. 1991. "Relaciones Interétnicas en el Caribe Indígena: Una Reconstrucción a Partir de los Primeros Testimonios Europeos." Revista de Indias 51 (193): 571-606.

Antczak, Andrzej T. and Maria M. Antczak. 2015a. "Revisiting the Early 16th-Century Town of Nueva Cádiz de Cubagua, Venezuela." Paper presented at the ist EAA-SAA Joint Meeting Connecting Continents, Curaçao, 24-27 November. 
Antczak, Maria M. and Andrzej T. Antczak. 2006. Los Ídolos de las Islas Prometidas: Arqueología Prehispánica del Archipiélago de Los Roques. Caracas: Editorial Equinoccio.

Antczak, Maria M. and Andrzej T. Antczak. 2015b. "Late Pre-Colonial and Early Colonial Archaeology of the Las Aves Archipelagos, Venezuela." Contributions in New World Archaeology 8: 1-37.

Antczak, Andrzej T., Maria M. Antczak, Roberto Valcárcel Rojas, and Andrej Sýkora. 2015. "Rethinking guanín: The role of northern Venezuela in circulation and valuation of Indigenous metal objects in the Circum-Caribbean macroregion." Paper presented at the 26th Congress of the International Association for Caribbean Archaeology, Sint Maarten, 19-25July.

Arcila Farías, Eduardo. 1946. Economía Colonial de Venezuela. México: Fondo de Cultura Económica.

Arcila Farías, Eduardo. 1983. Hacienda y comercio de Venezuela en el siglo XVI. Caracass: Banco Central de Venezuela.

Arellano Moreno, Antonio. 1950. Fuentes para la Historia Económica de Venezuela (siglo $X V I)$. Caracas: Tercera Conferencia Interamericana de Agricultura.

Armand, Jorge N. 2017. Nueva Cádiz de Cubagua (1502-1545): Parábola de la Venezuela Pospetrolera. Balti: Editorial Académica Española.

Arreaza-Camero, Emperatriz. 1993. "Cubagua, or the search for Venezuelan national identity." Iowa Journal of Cultural Studies 12: 108-131.

Ayala Lafée-Wilbert, Cecilia and Werner Wilbert. 2011. Memoria Histórica de los Resguardos Guayqueríes: Propiedady Territorialidad Tradicional. Caracas: Ediciones IVIC.

Azócar de Campos, Elba. 20o9. Cubagua: Mas Allá del Signo. Caracas: Universidad Simón Bolívar.

Bénat Tachot, Louise. 2015. "L'île de Cubagua. Réflexions sur les mécanismes et les enjeux de la société coloniale des Caraibes au XVIe siècle." In A la recherche du Carä̈be Perdu, edited by Bernard Grunberg, 285-304. Paris: L'Harmattan.

Benzoni, Girolamo. (1565) 1991. "Historia del Mondo Nuovo [1565]." In Nuovo Mondo. Gli Italiani, 1492-1565, edited by Paolo Collo and Pier L. Crovetto, 547-589. Torino: Giulio Einaudi Editore.

Biord Castillo, Horacio. 1985. "El contexto multilingüe del sistema de interdependencia regional del Orinoco." Antropológica 63/64: 83-103.

Biord Castillo, Horacio and Lilliam Arvelo. 2007. "Conexiones Interétnicas entre el Orinoco y el Mar Caribe en el siglo xvi: La región centro-norte de Venezuela." In Lecturas Antropológicas de Venezuela, edited by Lino Meneses Pacheco, Gladys Gordones, and Jacqueline Clarac de Briceño, 239-245. Mérida: Editorial Venezolana.

Booy, Theodoor de. 1916. Notes on the Archaeology of Margarita Island, Venezuela. New York: The Museum of the American Indian. 
Boulton, Alfredo. 1961. La Margarita. Caracas: Ediciones Macanao.

Bry, Theodor de. 1990. America de Bry. Berlin and New York: Casablanca Verlag.

Brito Figueroa, Federico. 1966. Historia económica y social de Venezuela. Caracas: Universidad Central de Venezuela.

Camargo, R. Marcela. 1983. "Las pesquerías de perlas y conchas madreperla en Panamá." Lotería 326: 32-76.

Campos, S. Corina and G. Oswaldo Guzmán. 2002. "Estratigrafía Secuencial y Sedimentología de las Facies Turbidíticas del Flysch Eoceno de la Isla de Margarita, Edo. Nueva Esparta, Venezuela." PhD diss., Universidad Central de Venezuela.

Cantino, Alberto. (1501) 1989. "Carta de Alberto Cantino al Excmo. Principe Hercules I Duque de Ferrara, Lisboa, 17 de Octubre de 1501." In El Mar de los Descubridores, edited by Marisa Vannini de Gerulewicz, 41-43. Caracas: Fundación de Promoción Cultural de Venezuela.

Capelo, Juan C. and Joaquín Buitrago. 1998. "Distribución Geográfica de los Moluscos Marinos en el Oriente de Venezuela." Memoria Sociedad de Ciencias Naturales La Salle 58 (150): 109-160.

Carballo, Álvarez L. 2014. "Cambios de Los Paisajes Ancestrales de la Isla de Cubagua (400o A.C.-1955 D.C.), Arqueología y Etnohistoria.” Master thesis, Instituto Venezolano de Investigaciones Científicas (IVIC).

Carballo, Álvarez L. 2017. "Paisajes Ancestrales de la Isla de Cubagua (4000 A.C.-1500 D.C.)." Boletín Antropológico 35 (93): 7-31.

Casas, Paola, William Villalba, and Roberta Crescini. 2015. "Producción Específica de la Pepitona Arca zebra (Swainson, 1833) en la Bahía de Charagato, Isla de Cubagua, Venezuela." Saber 27 (4): 659-667.

Castellanos, Juan de. (1589) 1987. Elegías de Varones Ilustres de Indias. Caracas: Biblioteca de la Academia Nacional de la Historia.

Castillo Hidalgo, Ricardo I. 2005. Asentamiento Español y Articulación Interétnica en Cumaná (1560-1620). Caracas: Biblioteca de la Academia Nacional de La Historia.

Cervigón, Fernando M. 1997. Cubagua: 500 Años. Margarita: Fundación Museo del Mar.

Cervigón, Fernando M. 1998a. Las Perlas en la Historia de Venezuela. Margarita: Fundación Museo del Mar.

Cervigón, Fernando M. 1998b. La Perla. Margarita: Fondo para el Desarrollo del Estado Nueva Esparta.

Champlain, Samuel de. 1989. "Breve Discurso sobre las Cosas más Notables que Samuel Champlain de Brouages ha Encontrado en las Indias Occidentales en el Viaje que Hizo a Ellas en el Año de 1599 y en el Año de 1601 como Sigue." In El Mar de los Descubridores, edited by Marisa Vannini de Gerulewicz, 201-238. Caracas: Fundación de Promoción Cultural de Venezuela.

Cipriani, Roberto, Héctor M. Guzmán, and Melina López. 2008. “Harvest History and Current Densities of the Pearl Oyster Pinctada mazatlanica (Bivalvia: Pteriidae) in 
Las Perlas and Coiba Archipelagos, Panama." Journal of Shellfish Research 27 (4): 691-700.

Cipriani, Roberto, César Lodeiros, and Andrzej T. Antczak. 2010. "The exploitation of the Atlantic Pearl Oyster during early 1500's in the eastern coast of Venezuela." Paper presented at the 14oth Annual Meeting of the American Fisheries Society, Pittsburgh, Pennsylvania, 12-16 September.

Colón, Cristóbal. (1498) 1997. "La historia del viaje que el Almirante Don Cristóbal Colón hizo la tercera vez que vino a las Indias cuando descubrió la Tierra Firme, como la envió a los Reyes desde la Isla Española." In Margarita y Cubagua en el Paraíso de Colón, edited by Alí E. López Bohórquez, 71-83. Mérida: Universidad de Los Andes.

Cruxent, José M. 1955. “Nueva Cádiz: Testimonio de Piedra.” El Farol 159 (17): 2-5.

Cruxent, José M. 1964. "Cuentas de collar de vidrio de sección estrellada." Boletín Informativo IVIC 3: 10-12.

Cruxent, José M. 1969. "Plano de Nueva Cádiz, Isla de Cubagua, Venezuela." Boletín Informativo IVIC 6: 6.

Cruxent, José M. 1972. "Algunas Noticias sobre Nueva Cádiz (Isla de Cubagua), Venezuela." Memorias vi Conferencia Geológica del Caribe, Isla de Margarita, 6-14 July: 33-35. Caracas.

Cruxent, José M. 1980. Notas ceramología: Algunas sugerencias sobre la práctica de la descripción de las cerámicas arqueológicas de la época Indo-Hispana, Cuaderno Falconiano 3. Coro: Ediciones UNEFM.

Cruxent, José M. and J. Eduardo Vaz. 1978. "Provenience studies of majolica pottery: Type Ichtucknee Blue on Blue.” In Archaeological essays in honor of Irving B. Rouse, edited by Robert C. Dunnell and Edwin S. Hall, 343-374. The Hague: Mouton.

Cruxent, José M. and Maruja Rolando. 1961. "Tipología Morfológica de Tres Piezas de Cerámica; Nueva Cádiz, Isla de Cubagua." Boletín Informativo IVIC 2: 7-19.

Cruxent, José M. and Irving Rouse. 1958. Arqueología Cronológica de Venezuela (2 vols.). Caracas: Ernesto Armitano.

Cunnil Grau, Pedro. 1993. "Geografía y Poblamiento de Venezuela Hispánica." In Los Tres Primeros Siglos de Venezuela, 1498-1810, edited by Pedro Grases, 3-94. Caracas: Grijalbo.

Cunnil Grau, Pedro. 2004. "Biodiversidad y recursos naturales venezolanos para la sensibilidad euroamericana: sus paisajes geohistóricos siglos XV-XIX." Boletín de la Academia Nacional de la Historia (Venezuela) 87 (346): 25-156.

Dalton, Leonard V. 1912. Venezuela. New York: Charles Scribner's Sons.

Dawson, Kevin. 2006. "Enslaved swimmers and divers in the Atlantic World." The Journal of American History 92 (4): 1327-1355.

Deagan, Kathleen A. 2003. "Colonial Origins and Colonial Transformations in Spanish America." Historical Archaeology 37 (4): $3^{-13}$. 
Domínguez, Lourdes. 1978. "La transculturación en Cuba (s. XVI-xvii)." Cuba Arqueológica 1: 33-50.

Donkin, Robin A. 1998. Beyond Price. Pearls and Pearl Fishing: Origins to the Age of Discoveries. Philadelphia: American Philosophical Society.

Fernández de Oviedo y Valdéz, Gonzalo. (1535) 1986. Historia General y Natural de las Indias, Islas y Tierra Firme del Mar Océano. Caracas: Biblioteca de la Academia Nacional de la Historia.

Ferris, Carmen L. 1991. "Nueva Cádiz de Cubagua. Aspectos Históricos y Arqueológicos." Tierra Firme 9 (9): 185-197.

Gabaldón Márquez, Joaquín (ed). 1988. Descubrimiento y Conquista de Venezuela, Vol. 2: Cubagua y la Empresa de los Belzares. Caracas: Biblioteca de la Academia Nacional de la Historia.

Galtsoff, Paul S. 1950. "The Pearl Fishery of Venezuela." Special Scientific Report Fisheries 26: 1-26.

Gerhard, Peter. 1956. "Pearl Diving in Lower California, 1533-1830." Pacific Historical Review 25 (3): 239-249.

Ginés, Hno., Fr. Cayetano de Carrocera, José M. Cruxent, and Jesús M. Rísquez. 1946. "Manicuare." Memorias de la Sociedad de Ciencias Naturales La Salle 16: 157-200.

Goggin, John M. 1960. The Spanish Olive Jar. An Introductory Study. New Haven: Yale University.

Goggin, John M. 1968. Spanish majolica in the New World: types of the sixteenth to eighteenth centuries. New Haven: Yale University.

Gómez, Ángel Félix. 2004. Margarita 1757; Censo del Gobernador Alonso del Río y Castro Juan Griego: Alcaldía de Marcano.

González, Taliana L. 2002. "Pesquería de perlas durante la colonia en Nuestra Señora de los Remedios del Cabo de la Vela al Río de La Hacha (1538-1545)." Jangwa Pana 2: $26-34$.

Gosden, Chris. 2004. Archaeology and Colonialism: Cultural Contact from 5000 BC to the Present. Cambridge: Cambridge University Press.

Guerra Curvelo, Weildler. 1997. "La ranchería de las perlas del Cabo de la Vela (15381550)." Huellas 49/50: 33-51.

Harrison, Rodney. 2014. "Shared Histories: Rethinking 'Colonized' and 'Colonizer' in the Archaeology of Colonialism." In Rethinking Colonial Pasts through Archaeology, edited by Neal Ferris, Rodney Harrison, and Michael V. Wilcox, 37-57. Oxford: Oxford University Press.

Heinen, H. Dieter and Alvaro García-Castro. 2000. "The Multiethnic Network of the Lower Orinoco in Early Colonial Times." Ethnohistory 47 (3/4): 361-379.

Helmer, Marie. 1962. "Cubagua, l'ile des perles." Annales 17: 751-760.

Henley, Paul. 1985. "Reconstructing Chaima and Cumanagoto kinship categories: An exercise in 'tracking down ethnohistorical connections." Antropológica 63/64:151-197. 
Hernández-Ávila, Iván, Alejandro Tagliafico, and Nestor Rago. 2013. “Composition and structure of the macrofauna associated with beds of two bivalve species in Cubagua Island, Venezuela." Revista de Biología Tropical 61 (2): 669-682.

Humboldt, Alexander von. (1814-1825) 1995. Personal Narrative of a Journey to the Equinoctial Regions of the New Continent. London: Penguin Books.

Ingold, Timothy. 2007. Lines: A Brief History. Abingdon: Routledge.

Idyll, Clarence P. 1965. "The Pearls of Margarita." Sea Frontier 11 (5): 268-280.

Instituto del Patrimonio Cultural. 2009. Cubagua: Parque Arqueológico, Paleontológico y Geológico. Caracas: Instituto del Patrimonio Cultural.

Jiménez, G. Morella A. 1986. La Esclavitud Indígena en Venezuela (Siglo XVI). Caracas: Fuentes para la Historia Colonial de Venezuela.

Las Casas, Bartolomé de. 1981. Historia de las Indias, por Fray Bartolomé de Las Casas, Libro II. México: Fondo de Cultura Económica.

Las Casas, Bartolomé de. 1997. "Historia de las Indias." In Margarita y Cubagua en el Paraíso de Colón, edited by Alí E. López Bohórquez, 119-182. Mérida: Universidad de Los Andes.

Lister, Florence C. and Robert H. Lister. 1974. "Maiolica in Colonial Spanish America." Historical Archaeology 8 (1): 17-52.

López de Gómara, Francisco. (1552) 1988. "Historia General de Las Indias." In Cronistas y Primitivos Historiadores de la Tierra Firme, Vol. 1, edited by Horacio J. Becco, 161-184. Caracas: Fundación de Promoción Cultural de Venezuela.

MacKenzie, Jr., Clyde L., Luis Troccoli, and León B. León. 2003. "History of the Atlantic Pearl-Oyster, Pinctata imbricata, industry in Venezuela and Colombia, with biological and ecological observations." Marine Fisheries Review 65 (1): 1-20.

Mártir de Anglería, Pedro. (1530) 1988. "Décadas del Nuevo Mundo." In Cronistas y Primitivos Historiadores de la Tierra Firme, Vol. 1, edited by Horacio J. Becco, 47-84. Caracas: Fundación de Promoción Cultural de Venezuela.

McCorkle, Thomas. 1965. Fajardo's people: Cultural Adjustment in Venezuela and the Little Community in Latin American and North American Contexts. Los Angeles: University of California.

Mira Caballos, Esteban. 1997. El Indio Antillano: repartimiento, encomienda y esclavitud (1492-1524). Sevilla-Bogotá: Muñoz Moya Editor.

Morón, Guillermo. 1954. Los orígenes históricos de Venezuela. Introducción al Siglo XVI. Madrid: Consejo Superior de Investigaciones Científicas.

Mosk, Sanford A. 1938. "Spanish pearl-fishing operations on the Pearl Coast in the Sixteenth Century." The Hispanic American Historical Society Review 18: 392-400.

Nectario Maria, Hno. 1960. El Gran Santuario de Venezuela: La Virgen del Valle de Margarita. Madrid: Imprenta Juan Bravo.

Nuñez, Enrique B. 1988. Cubagua. Caracas: Monte Ávila.

O’Brian, Patrick, ed. 1996. The Drake Manuscript. London: André Deutsch Limited. 
Ocanto, David and Félix Baptista. 1998. Presagios de tierra y fuego: Análisis de la cerámica popular en El Cercado, Margarita. Caracas: Consejo Nacional de la Cultura.

Orche, Enrique G. 2009. "Exploitation of Pearl Fisheries in the Spanish American Colonies." De Re Metallica 13: 19-33.

Otte, Enrique. 1961, Cedulario de la Monarquía Española Relativo a la Isla de Cubagua (1523-1550), Vol. 1, 1523-1534. Caracas: Fundación John Boulton y la Fundación Eugenio Mendoza.

Otte, Enrique. 1977. Las Perlas del Caribe: Nueva Cádiz de Cubagua. Caracas: Fundación John Boulton.

Pacheco, Carlos, Luis Barrera Linares, and Beatriz González Stephan, eds. 2006. Nación y Literatura: Itinerarios de la palabra escrita en la cultura Venezolana. Caracas: Fundación Bigott.

Perera, Miguel A. 2000. Oro y hambre: Guyana siglo XVI:Ecología culturaly Antropología Histórica de un Malentendido 1498-1597. Caracas: Universidad Central de Venezuela.

Perri, Michael H. 2009. "'Ruined and Lost': Spanish Destruction of the Pearl Coast in the Early Sixteenth Century." Environment and History 15 (2): 129-161.

Pinto, Manuel C. 1967. Visión Documental de Margarita. La Asunción: Ejecutivo del Estado Nueva Esparta.

Quiévreux, Henry. 1900. "La pêche des perles au Venezuela." La Revue Maritime 146: 444-448.

Ramos, Demetrio. 1976. Estudio de Historia Venezolana. Caracas: Fuentes para la Historia Colonial de Venezuela.

Rivas, Pedro. 2001. "Arqueología de los procesos de etnogénesis y ocupación territorial en la región norcentral de Venezuela." In La arqueología venezolana en el nuevo milenio, edited by Lino Meneses and Gladys R. Gordones, 211-273. Mérida: Universidad de Los Andes.

Rodríguez Velásquez, Fidel. 2017. "Representación e historiografía: miradas múltiples al pasado de la Isla de Cubagua (1892-2014)." Ouro Preto 23: 28-42.

Rojas, Weimber J. 2010. "Incidencia de la agricultura en el contexto económico de la isla de Margarita durante la segunda mitad del siglo XVIII." Tiempo y Espacio 30 (53): 40-66.

Rojas, Arístides. 2008. Orígenes Venezolanos: Historia, Tradiciones, Crónicas y Leyendas. Caracas: Fundación Biblioteca Ayacucho.

Romero, Aldemaro. 2003. "Death and Taxes: the Case of the Depletion of Pearl Oyster Beds in Sixteenth-Century Venezuela." Conservation Biology 17 (4): 1013-1023.

Romero, Aldemaro, Susanna Gilbert, and M.G. Eisenhart. 1999. "Cubagua's Pearl-Oyster Beds: The First Depletion of a Natural Resource Caused by Europeans in the American Continent." Journal of Political Ecology 6: 57-78.

Rouse, Irving and José M. Cruxent. 1963. Venezuelan archaeology. New Haven: Yale University Press. 
Rugil. 1892. "Historia Patria: El Escudo de Cubagua." Cojo Ilustrado 1(6).

Salaya, Juan J. and Luis Salazar. 1972. Exploraciones y Explotaciones de la Ostra Perla (Pinctada imbricata) en Venezuela, 1946-1969, Informe técnico 44. Caracas: Ministerio de Agricultura y Cría.

Sanoja, Obediente M. and Iraida Vargas Arenas. 1999. Orígenes de Venezuela: Regiones Geohistóricas Aborígenes hasta 1500 d.c. Caracas: Comisión Presidencial v Centenario de Venezuela.

Sauer, Carl O. 1966. The Early Spanish Main. Berkeley and Los Angeles: University of California Press.

Scaramelli, Franz and Kay Tarble de Scaramelli 2005. "The Roles of Material Culture in the Colonization of the Orinoco, Venezuela." Journal of Social Archaeology 5 (1): 135-168.

Silliman, Stephen W. 2009. "Change and Continuity, Practice and Memory: Native American Persistence in Colonial New England." American Antiquity 74 (2): 211-230.

Silliman, Stephen W. 2014. "Archaeologies of Indigenous Survivance and Residence: Navigating Colonial and Scholarly Dualities." In Rethinking Colonial Pasts through Archaeology, edited by Neal Ferris, Rodney Harrison, and Michael V. Wilcox, 57-75. Oxford: Oxford University Press.

Silliman, Stephen W. 2015. "A requiem for hybridity? The problem with Frankensteins, purées, and mules." Journal of Social Archaeology 15 (3): 277-298.

Sluyter, Andrew. 2001. "Colonialism and Landscape in the Americas: Material/ Conceptual Transformations and Continuing Consequences." Annals of the Association of American Geographers 91 (2): 410-429.

Suárez, Carlos. 2014. “Arqueología, Representación y Patrimonio: Las 'otras historias' de Cubagua y Nueva Cádiz." Nuestro Sur 5 (8): 41-57.

Subero, Jesús M. 1996. Pespunteo en la Cronología Histórica de Margarita. Porlamar: Editorial Benavente and Martínez.

Tagliafico, Alejandro, María S. Rangel, and Néstor Rago. 2012. "Distribución, Densidad y Estructura de Tallas del Genero Strombus de la Isla Cubagua, Venezuela." Interciencia 37 (5): 381-389.

Thomas, Julian. 2017. "Landscape, Taskscape, Life." In Forms of Dwelling: 20 years of Taskscapes in archaeology, edited by U. Rajala and P. Mills, pp. 268-279. Oxford: Oxbow Books.

Tiapa, Francisco. 2008. "Resistencia indígena e identidades fronterizas en la colonización del Oriente de Venezuela, siglos XVI-XVIII." Antropológica 109: 69-112.

Vásquez, Socorro. 1989. "Pesquerías de Perlas del Cabo de La Vela." Boletín de Antropología 4 (4): 45-48.

Vaz, J. Eduardo and José M. Cruxent. 1978. "Gamma-Ray induced thermoluminescence of majolica pottery as an indicator of its provenience." Revista Española de Antropología Americana 8: 49-54. 
Vela Cossio, Fernando and Alejandro García Hermida, eds. 2014. Arqueología de los primeros asentamientos urbanos españoles en la America Central y Meridional. Madrid: Edita Mairea Libros.

Velásquez, Justo S. 1956. "Petróleo y Perlas de Cubagua." Revista Shell (5): 44-52.

Vila, Pau. 1948. "La destrucción de Nueva Cádiz. ¿Terremoto o huracán?" Boletín Academia Nacional de la Historia 31 (123): 213-219.

Vila, Pau. 1961. "Cubagua y el Poblamiento Oriental de Venezuela en los Comienzos de la Colonia." In Miscellània Fontserè, edited by Gustavo Gili, 435-443. Barcelona: Gustavo Gili.

Vila, Pau. 1963. "Las Actividades Perlíferas y sus Vicisitudes en Venezuela." Revista de Historia 3 (17): 13-37.

Vila, Marco-Aurelio. 1978. La Geoeconomía de la Venezuela del siglo XVI. Caracas: Universidad Central de Venezuela.

Villamizar, G., Estrella Y. and Fernando Cervigón. 2017. "Variability and sustainability of the Southern Subarea of the Caribbean Sea large marine ecosystem." Environmental Development 22: 30-41.

Verde, Simone del. (1499) 1989. "Carta de Simone del Verde a Mateo Cini, Cádiz, 2 de Enero del 1499." In El Mar de los Descubridores, edited by Marisa Vannini de Gerulewicz, 38-39. Caracas: Fundación de Promoción Cultural de Venezuela.

Voss, Barbara L. and Eleanor C. Casella, eds. 2012. The Archaeology of Colonialism: Intimate Encounters and Sexual Effects. Cambridge: Cambridge University Press.

Warsh, Molly A. 2010. "Enslaved Pearl Divers in the Sixteenth Century Caribbean." Slavery and Abolition 31 (3): 345-362.

Warsh, Molly A. 2018. American Baroque: Pearls and the Nature of Empire, 1492-1700. Chapel Hill: The University of North Carolina Press.

Willis, Raymond F. 1976. "The Archaeology of 16th Century Nueva Cádiz." Master thesis, University of Florida.

Willis, Raymond F. 1980. "Nueva Cádiz." In Spanish Colonial Frontier Research, edited by Henry F. Dobyns, 27-40. Albuquerque: Center for Anthropological Studies.

Wing, Elizabeth S. 1961. "Animal Remains Excavated at the Spanish Site of Nueva Cádiz on Cubagua Island, Venezuela." Nieve West-Indische Gids 41 (2): 162-165.

Woodruff Stone, Erin. 2014. "Indian Harvest:The Rise of the Indigenous Slave Trade and Diaspora from Española to the Circum-Caribbean, 1492-1542." PhD diss., Vanderbilt University.

Zubiri, Maria T. 2002. "Gobierno y Perleros en la Costa Venezolana a Inicios del siglo XVI." In Conflicto y Violencia en América: viii Encuentro-Debate América Latina ayery hoy, edited by Gabriela Dalla Corte, Pedro García Jordán, Miquel Izard, Javier Laviña, Ricardo Piqueras, Meritxell Tous, and Maria T. Zubiri, 69-73. Barcelona: Universidad de Barcelona. 